\title{
Bellilinea caldifistulae gen. nov., sp. nov. and Longilinea arvoryzae gen. nov., sp. nov., strictly anaerobic, filamentous bacteria of the phylum Chloroflexi isolated from methanogenic propionate-degrading consortia
}

\section{Correspondence \\ Yuji Sekiguchi y.sekiguchi@aist.go.jp}

Takeshi Yamada, ${ }^{1,2}$ Hiroyuki Imachi, ${ }^{2,3}$ Akiyoshi Ohashi, ${ }^{2}$ Hideki Harada, ${ }^{2,4}$
Satoshi Hanada, ${ }^{1}$ Yoichi Kamagata ${ }^{1,2,5}$ and Yuji Sekiguchi ${ }^{1,2}$

${ }^{1}$ Institute for Biological Resources and Functions, National Institute of Advanced Industrial Science and Technology (AIST), Tsukuba, Ibaraki 305-8566, Japan

${ }^{2}$ Department of Environmental Systems Engineering, Nagaoka University of Technology, Nagaoka, Niigata 940-2188, Japan

${ }^{3}$ Subground Animalcule Retrieval Program, Extremobiosphere Research Center, Japan Agency for Marine-Earth Science \& Technology (JAMSTEC), Yokosuka, Kanagawa 237-0061, Japan

${ }^{4}$ Department of Civil Engineering, Tohoku University, Sendai, Miyagi 980-8579, Japan

${ }^{5}$ Research Institute of Genome-based Biofactory, National Institute of Advanced Industrial Science and Technology (AIST), Sapporo, Hokkaido 062-8517, Japan

Thermophilic (strain $\mathrm{GOMI}-1^{\top}$ ) and mesophilic (strain $\mathrm{KOME}-1^{\top}$ ) strains were isolated from two different cultures of propionate-degrading consortia obtained from thermophilic digester sludge and rice paddy soil, respectively. The two strains were non-spore-forming, non-motile and Gram-negative. Both strains were obligately anaerobic micro-organisms, showing multicellular filamentous morphotypes more than $100 \mu \mathrm{m}$ in length. The cell width for strain $\mathrm{GOMl}-1^{\top}$ was 0.2-0.4 $\mu \mathrm{m}$ and that of strain $\mathrm{KOME}-1^{\top}$ was $0.4-0.6 \mu \mathrm{m}$. Strain GOMl-1 ${ }^{\top}$ could grow at $45-65{ }^{\circ} \mathrm{C}$ with a pH range of $6.0-7.5$ (optimum growth at $55^{\circ} \mathrm{C}, \mathrm{pH} 7.0$ ). The temperature range for growth of strain $\mathrm{KOME}-1^{\top}$ was $30-40{ }^{\circ} \mathrm{C}$ and the $\mathrm{pH}$ range was $\mathrm{pH}$ 5.0-8.5 (optimum growth around $37{ }^{\circ} \mathrm{C}, \mathrm{pH} \mathrm{7.0)}$. Yeast extract was required for growth of both strains. Strain GOMl-1 ${ }^{\top}$ was able to grow with a number of carbohydrates in the presence of yeast extract. In yeast extract-containing medium, strain $\mathrm{KOME}-1^{\top}$ could utilize proteins and a limited range of sugars for growth. The $\mathrm{G}+\mathrm{C}$ contents of the DNA of strains $\mathrm{GOMl}-1^{\top}$ and $\mathrm{KOME}-1^{\top}$ were respectively 54.7 and 57.6 mol\%. Major fatty acids of strain GOMl-1 ${ }^{\top}$ were $\mathrm{C}_{16: 0,}, \mathrm{C}_{14: 0}$ and iso- $C_{15: 0}$, whereas those of strain KOME-1 ${ }^{\top}$ were iso- $C_{15: 0}$, anteiso- $C_{15: 0}$ and $C_{14: 0}$. Based on comparative analysis of $16 \mathrm{~S}$ rRNA gene sequences of strains $\mathrm{GOMl}-1^{\top}$ and $\mathrm{KOME}-1^{\top}$, the strains were placed in different phylogenetic positions in the class Anaerolineae of the bacterial phylum Chloroflexi. Their phenotypic and genetic traits strongly supported the conclusion that the strains should be described as two independent taxa in the class Anaerolineae. Hence, we propose the names Bellilinea caldifistulae gen. nov., sp. nov., and Longilinea arvoryzae gen. nov., sp. nov., for strains $\mathrm{GOMI}-1^{\top}$ and $\mathrm{KOME}-1^{\top}$. The type strains of Bellilinea caldifistulae and Longilinea arvoryzae are respectively $\mathrm{GOMl}-1^{\top}\left(=\mathrm{JCM} 13669^{\top}=\mathrm{DSM} 17877^{\top}\right)$ and $\mathrm{KOME}-1^{\top}$ $\left(=\operatorname{JCM} 13670^{\top}=\right.$ KTCC $\left.5380^{\top}\right)$.
Abbreviations: NTA, nitrilotriacetate; UASB, upflow anaerobic sludge blanket.

The GenBank/EMBL/DDBJ accession numbers for the 16S rRNA gene sequences of strains $\mathrm{GOMl}-1^{\top}$ and $\mathrm{KOME}-1^{\top}$ are respectively AB243672 and AB243673.
The class Anaerolineae has recently been proposed as a subclade in the phylum Chloroflexi with the related new class Caldilineae (Yamada et al., 2006). Analyses based on sequences of $16 \mathrm{~S}$ rRNA and the 16S rRNA gene have revealed that members of this class are distributed widely in various types of ecosystems, such as the subsurface, 
sediments, hot springs and aerobic and anaerobic sludge (Björnsson et al., 2002; Hugenholtz et al., 1998a; Kindaichi et al., 2004; Sekiguchi et al., 1998; Teske et al., 2002), suggesting their ubiquity and functional significance in such environments (Hugenholtz et al., 1998b). However, the Anaerolineae have long been considered a group of the yet-to-be-cultured microbes that are recalcitrant to cultivation and isolation (Hugenholtz et al., 1998b; Sekiguchi et al., 2001). Recently, the first tangible micro-organism of the class was isolated and named Anaerolinea thermophila (Sekiguchi et al., 2001, 2003). In addition, three filamentous strains belonging to the class (representing Anaerolinea thermolimosa, Levilinea saccharolytica and Leptolinea tardivitalis) were further isolated and characterized (Yamada et al., 2005, 2006). So far, these four strains are the only known organisms able to be cultivated and thoroughly described in the class Anaerolineae. They are strictly anaerobic, multicellular filamentous microbes and can utilize a number of carbohydrates fermentatively in the presence of yeast extract (Sekiguchi et al., 2001, 2003; Yamada et al., 2005, 2006). Some of the strains require syntrophic association with a hydrogenotrophic methanogen for efficient growth (Sekiguchi et al., 2001, 2003; Yamada et al., 2005, 2006).

To date, all authentic species of the Anaerolineae have been initially found in and isolated from a special wastewater treatment system operating under anaerobic conditions called the upflow anaerobic sludge blanket (UASB) system. However, besides the UASB system, there are many anaerobic ecosystems in natural and artificial environments, and it is quite likely that an enormous number of unknown species of the Anaerolineae are hidden in such environments. We therefore searched anaerobic environments other than UASB sludges for novel species of the Anaerolineae. As a result, we successfully isolated two Anaerolineae-type filamentous anaerobes, designated strains GOMI- $1^{\mathrm{T}}$ and KOME- $1^{\mathrm{T}}$, from a thermophilic digester sludge and rice paddy soil, respectively. In this report, the isolation and detailed morphological, physiological and chemotaxonomic characteristics and genetic features of the strains are described, assigning taxonomic placements to the strains in the class Anaerolineae.

The two filamentous strains were isolated from thermophilic $\left(55{ }^{\circ} \mathrm{C}\right)$ and mesophilic $\left(37^{\circ} \mathrm{C}\right)$ methanogenic propionate-degrading consortia enriched from thermophilic digester sludge $\left(55^{\circ} \mathrm{C}\right)$ and rice paddy soil, respectively. Both consortia contained propionate-degrading Pelotomaculum spp. and hydrogenotrophic methanogens (Imachi et al., 2006). Besides these organisms, various morphotypes such as ovals, rods or filaments were observed in the enrichment cultures. Fluorescence in situ hybridization using the Chloroflexi-specific probe GNSB941* (Yamada et al., 2005) was performed according to previous reports (Sekiguchi et al., 1999; Yamada et al., 2005). The analysis showed that $\mathrm{GNSB} 941^{\star}$ probe-reactive filamentous cells were present as a significant constituent in the two enrichments. To isolate GNSB941*-positive filamentous cells that possibly belonged to the Anaerolineae from the cultures, we first transferred part of the enrichments to a fresh medium supplemented with sucrose $(20 \mathrm{mM})$ and yeast extract $(0.1 \%)$, because species of the Anaerolineae are commonly known as saccharolytic anaerobes that require yeast extract. The medium used for isolation and cultivation of the filamentous bacteria was prepared as described previously (Sekiguchi et al., 2000; Yamada et al., 2005). Primary enrichment cultures inoculated with thermophilic digester sludge and rice paddy soil were cultivated anaerobically at $55{ }^{\circ} \mathrm{C}$ and $37{ }^{\circ} \mathrm{C}$, respectively. A number of successive transfers to fresh sucrose-yeast extract medium were conducted, and stable cultures that consisted mainly of the filamentous cells were finally established. Two strains, GOMI- $1^{\mathrm{T}}$ and KOME- $1^{\mathrm{T}}$, were isolated from these enriched cultures by the roll-tube isolation method (Hungate, 1969) with sucrose-yeast extract medium supplemented with purified agar (20 $\mathrm{g}$ agar noble $\mathrm{l}^{-1}$; Difco). Isolation of strains GOMI- $1^{\mathrm{T}}$ and KOME- $1^{\mathrm{T}}$ was performed at $55^{\circ} \mathrm{C}$ and $37^{\circ} \mathrm{C}$, respectively. Tiny, colourless, lens-shaped colonies, $0.1-0.2 \mathrm{~mm}$ in diameter, were formed within 1 month of cultivation in both cases.

For microscope observations, agar-coated slides were prepared and microbial cells were immobilized on the slides (Pfennig \& Wagener, 1986). Both strains (strains GOMI-1 ${ }^{\mathrm{T}}$ and KOME-1 ${ }^{\mathrm{T}}$ ) showed flexible filaments of indefinite length (generally longer than $100 \mu \mathrm{m}$ ) under the microscope (Olympus AX80T) (Fig. 1). Cell widths of strains GOMI- $1^{\mathrm{T}}$ and KOME- $1^{\mathrm{T}}$ were respectively $0.2-0.4 \mu \mathrm{m}$ and $0.4-0.6 \mu \mathrm{m}$ (Fig. 1). Gram-staining done according to Hucker's method (Doetsch, 1981) was negative for both strains. Spore formation was not observed in either strain under any culture conditions. Gliding motility was not observed (based on the observation of colony forms on solid agar medium).

Strains GOMI- $1^{\mathrm{T}}$ and KOME- $1^{\mathrm{T}}$ were obligately anaerobic, filamentous micro-organisms. Neither aerobic nor phototrophic growth in PE medium was observed in either strain (Hanada et al., 1995). The following physiological tests, nutritional properties, usage of electron acceptors, fermentative end products and acid formation, were done according to methods described previously (Imachi et al., 2000, 2002; Roden \& Lovley, 1993; Sekiguchi et al., 2000; Yamada et al., 2005). A small amount of yeast extract was required for growth in both strains. In the presence of yeast extract $(0.01 \%)$, strain $\mathrm{GOMI}-\mathrm{1}^{\mathrm{T}}$ could utilize the following substrates $(20 \mathrm{mM}$ each unless specified otherwise): ribose, arabinose, fructose, glucose, galactose, mannose, sucrose, raffinose and pectin $\left(5 \mathrm{~g} \mathrm{l}^{-1}\right)$. The following substrates supported weak growth of strain GOMI- $1^{\mathrm{T}}$ and caused acid formation in medium supplemented with yeast extract $(0.01 \%)$ (substrates added at a final concentration of $20 \mathrm{mM}$ unless mentioned otherwise): Casamino acids $(0.1 \%)$, tryptone $(0.1 \%)$, peptone $(0.1 \%)$, xylose and xylan $\left(5 \mathrm{~g} \mathrm{l}^{-1}\right)$. The following substrates tested did not support growth of strain GOMI- $1^{\mathrm{T}}$ and did not lead to acid formation even in the 

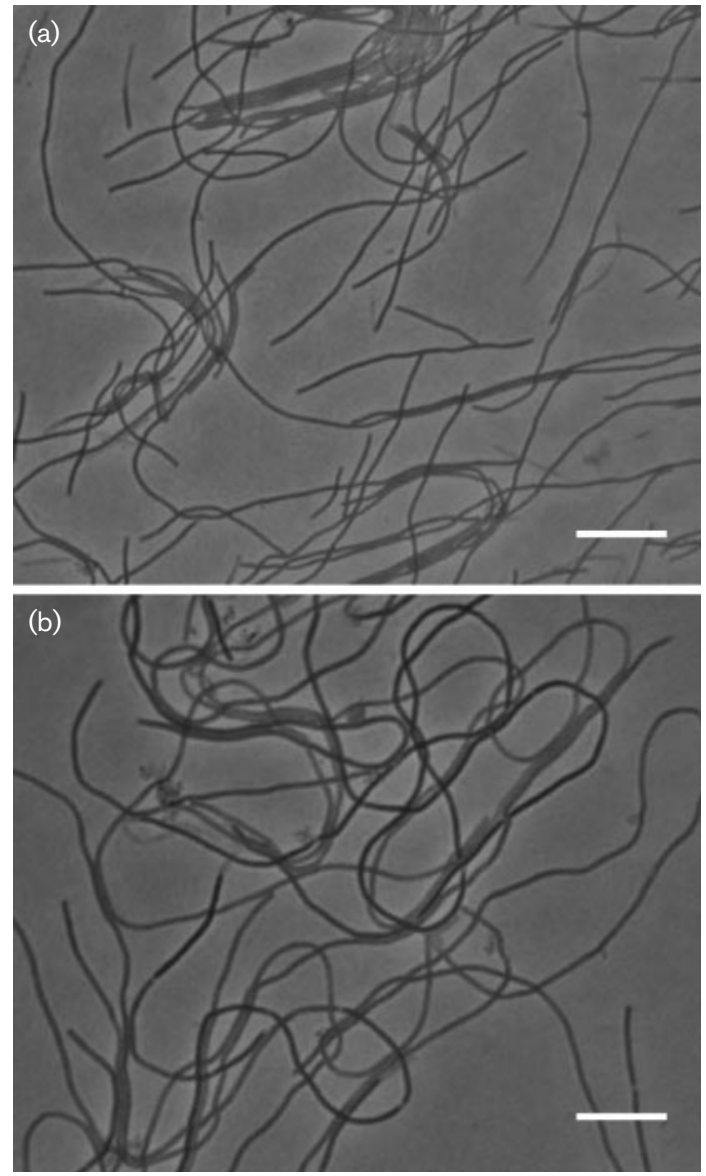

Fig. 1. Phase-contrast photomicrographs of strains $\mathrm{GOMl}-1^{\top}$ (a) and $\mathrm{KOME}-1^{\top}$ (b) grown on sucrose-yeast extract medium. Bars, $10 \mu \mathrm{m}$.

presence of yeast extract $(0.01 \%)(20 \mathrm{mM}$ each unless specified): crotonate, $\mathrm{H}_{2} / \mathrm{CO}_{2}$ (1 atm) plus acetate $(10 \mathrm{mM})$, betaine, lactate, glycerol, fumarate, acetate, propionate, butyrate, malate, succinate, ethanol, methanol, 1-propanol, starch, ethylene glycol, hydroquinone (1 mM), phenol $(1 \mathrm{mM})$, benzoate $(5 \mathrm{mM})$ and formate plus acetate $(10 \mathrm{mM})$.

Under parallel conditions, strain KOME- $1^{\mathrm{T}}$ could utilize the following substrates $(20 \mathrm{mM}$ each unless specified): tryptone $(0.1 \%)$, xylose, raffinose, sucrose, xylan $\left(5 \mathrm{~g} \mathrm{l}^{-1}\right)$, pectin $\left(5 \mathrm{~g} \mathrm{l}^{-1}\right)$ and peptone $(0.1 \%)$. Casamino acids $(0.1 \%)$ and fructose $(20 \mathrm{mM})$ led to weak growth and acid formation. None of the following substrates tested supported growth $(20 \mathrm{mM}$ each unless specified): pyruvate, glucose, ribose, arabinose, galactose, mannose, crotonate, $\mathrm{H}_{2} / \mathrm{CO}_{2}$ (1 atm) plus acetate $(10 \mathrm{mM})$, lactate, glycerol, fumarate, acetate, propionate, butyrate, malate, succinate, ethanol, methanol, 1-propanol, starch, ethylene glycol, hydroquinone $(1 \mathrm{mM})$, phenol $(1 \mathrm{mM})$, benzoate $(5 \mathrm{mM})$ and formate plus acetate $(10 \mathrm{mM})$, betaine and starch $\left(5 \mathrm{~g} \mathrm{l}^{-1}\right)$.
In medium containing sucrose $(20 \mathrm{mM})$ and yeast extract $(0.01 \%)$, major fermentative products of strain GOMI- $1^{\mathrm{T}}$ were acetate, lactate, formate and hydrogen. Small amounts of propionate and pyruvate were also produced. On the other hand, strain KOME- $1^{\mathrm{T}}$ produced only acetate, lactate and hydrogen as end products. Strains GOMI- $1^{\mathrm{T}}$ and KOME- $1^{\mathrm{T}}$ did not use any of the following electron acceptors within 4 weeks of incubation on sucrose-yeast extract medium: $20 \mathrm{mM}$ sulphate, $1 \mathrm{mM}$ sulphite, $20 \mathrm{mM}$ thiosulphate, $20 \mathrm{mM}$ elemental sulphur, $20 \mathrm{mM}$ nitrate, $20 \mathrm{mM}$ fumarate and $5 \mathrm{mM} \mathrm{Fe}(\mathrm{III})$ nitrilotriacetate (NTA).

Effects of $\mathrm{pH}$, temperature and $\mathrm{NaCl}$ concentration on growth of strains GOMI- $1^{\mathrm{T}}$ and KOME- $1^{\mathrm{T}}$ were determined by using the basal medium containing $20 \mathrm{mM}$ sucrose plus $0.1 \%$ yeast extract ( $2 \%$ inoculum). All tests were performed in triplicate and growth was evaluated by measuring optical density $\left(\mathrm{OD}_{400}\right)$ and formation of acid and hydrogen. Growth of strain GOMI- $1^{\mathrm{T}}$ occurred in a $\mathrm{pH}$ range of 6.0-7.5 and growth of strain KOME- $1^{\mathrm{T}}$ was observed between $\mathrm{pH} 5.0$ and 8.5 ; both strains showed optimum growth at around $\mathrm{pH}$ 7.0. The optimum growth temperature of strain GOMI- $1^{\mathrm{T}}$ was $55^{\circ} \mathrm{C}$ (growth occurred at $45-65^{\circ} \mathrm{C}$ ). Strain KOME- $1^{\mathrm{T}}$ could grow between 30 and $40{ }^{\circ} \mathrm{C}$ with an optimum temperature of around $37{ }^{\circ} \mathrm{C}$. The two strains were basically freshwater organisms, but they could tolerate significant amounts of salt. Strain GOMI- $1^{\mathrm{T}}$ could tolerate $\mathrm{NaCl}$ up to $30 \mathrm{~g} \mathrm{l}^{-1}$, while $\mathrm{KOME}_{-1}{ }^{\mathrm{T}}$ could not grow in $15 \mathrm{~g} \mathrm{NaCl}^{-1}$.

Under optimum growth conditions for strains GOMI- $1^{\mathrm{T}}$ $\left(55^{\circ} \mathrm{C}, \mathrm{pH} 7.0\right)$ and $\mathrm{KOME}-1^{\mathrm{T}}\left(37^{\circ} \mathrm{C}, \mathrm{pH} 7.0\right)$, doubling times on sucrose-yeast extract medium were respectively 45 and $92 \mathrm{~h}$ (evaluated by the method described previously; Sekiguchi et al., 2003; Yamada et al., 2006). Growth of each strain was found to stagnate after a certain amount of hydrogen accumulated in the vial. Co-culture with a hydrogen scavenger such as a methanogen prevented the hydrogen accumulation and obviously promoted growth. In the sucrose-yeast extract medium, syntrophic growth properties of the two strains with hydrogenotrophic methanogens were evaluated in co-cultivation with Methanospirillum hungatei DSM $864^{\mathrm{T}}$ for strain KOME- ${ }^{\mathrm{T}}$ and Methanothermobacter thermautotrophicus DSM $1053^{\mathrm{T}}$ for strain GOMI- $1^{\mathrm{T}}$. A significant increase in the growth rate was observed in co-culture of strain KOME- ${ }^{\mathrm{T}}$ with Methanospirillum hungatei DSM $864^{\mathrm{T}}$ and the doubling time decreased to $29 \mathrm{~h}$ (evaluated as described above). A similar result was obtained in co-culture of strain GOMI- $1^{\mathrm{T}}$ with Methanothermobacter thermautotrophicus DSM $1053^{\mathrm{T}}$, and the doubling time was $38 \mathrm{~h}$.

For determination of genomic DNA G + C contents, DNA of each isolate was extracted and purified as described previously (Kamagata \& Mikami, 1991) and analysed by HPLC (Shintani et al., 2000). The DNA G +C contents of strains GOMI- $1^{\mathrm{T}}$ and KOME- $1^{\mathrm{T}}$ were respectively 54.7 and $57.6 \mathrm{~mol} \%$. For cellular fatty acid methyl ester analysis 
(Hanada et al., 2002), cells of strains GOMI- ${ }^{\mathrm{T}}$ and KOME- $1^{\mathrm{T}}$ were harvested from cultures grown under optimum growth conditions with medium containing sucrose $(20 \mathrm{mM})$ plus yeast extract $(0.1 \%)$. The analyses showed that strain GOMI- $1^{\mathrm{T}}$ contained $\mathrm{C}_{16: 0}(28 \%), \mathrm{C}_{14: 0}$ $(24 \%)$ and iso- $\mathrm{C}_{15: 0}(13 \%)$ as the major cellular fatty acids, with $\mathrm{C}_{18: 0}(7 \%), \mathrm{C}_{16: 1} \Delta 9$ cis $(8 \%)$, branched $\mathrm{C}_{17: 0}$ $(5 \%)$, anteiso- $\mathrm{C}_{15: 0}(3 \%), \mathrm{C}_{18: 1} \Delta 9$ cis $(3 \%), \mathrm{C}_{12: 0}(2 \%)$, anteiso- $\mathrm{C}_{17: 0}(2 \%)$, iso- $\mathrm{C}_{17: 0}(1 \%)$, branched $\mathrm{C}_{13: 0}(1 \%)$, branched $\mathrm{C}_{14: 0}(1 \%)$, iso- $\mathrm{C}_{16: 0}(1 \%)$ and branched $\mathrm{C}_{18: 0}$ $(1 \%)$ as minor fatty acids. Strain KOME- $1^{\mathrm{T}}$ contained iso- $\mathrm{C}_{15: 0}(27 \%)$, anteiso- $\mathrm{C}_{15: 0}(24 \%)$ and $\mathrm{C}_{14: 0}(20 \%)$ as the major cellular fatty acids, with $\mathrm{C}_{16: 0}(8 \%)$, branched $\mathrm{C}_{13: 0}(6 \%)$, branched $\mathrm{C}_{14: 0}(5 \%), \mathrm{C}_{12: 0}(2 \%)$, anteiso$\mathrm{C}_{17: 0} \quad(2 \%), \mathrm{C}_{15: 0} \quad(1 \%), \mathrm{C}_{13: 0} \quad(1 \%), \mathrm{C}_{15: 0} \quad(1 \%)$, iso- $\mathrm{C}_{16: 0}(1 \%)$, branched $\mathrm{C}_{17: 0}(1 \%)$ and $\mathrm{C}_{18: 1} \Delta 9$ cis $(1 \%)$ as minor fatty acids. Quinone analysis by HPLC (Zhang et al., 2003) revealed that neither isolate contained any type of quinone.

To determine 16S rRNA gene sequences for both isolates, we extracted DNA from the strains with the methods of Hiraishi (1992). 16S rRNA genes were amplified with the bacteria-specific 16S rRNA gene-targeted primer set $8 \mathrm{f}$ $\left(5^{\prime}\right.$-AGAGTTTGATCCTGGCTCAG-3') and 1492r (5'GGTTACCTTGTTACGACTT-3') (Weisburg et al., 1991), and sequenced with a CEQ DTC kit-Quick start kit (Beckman Coulter) and a Beckman Coulter CEQ-2000 automated sequence analyser (Imachi et al., 2006; Yamada et al., 2005). Totals of $1425 \mathrm{nt}\left(\right.$ strain GOMI- ${ }^{\mathrm{T}}$ ) and 1422 nt (strain KOME- ${ }^{\mathrm{T}}$ ) were determined. Phylogenetic analysis based on the neighbour-joining method (Saitou \& Nei, 1987) with the ARB program (Ludwig et al., 2004) and the maximum-likelihood method with the TREEFINDER program (Jobb, 2007) indicated that the strains were affiliated with the class Anaerolineae (Fig. 2). However, they were clearly distant from any known species of the Anaerolineae. The most closely related organism to strain GOMI- $1^{\mathrm{T}}$ was Levilinea saccharolytica KIBI- ${ }^{\mathrm{T}}(1424 \mathrm{nt})$, with $93 \%$ 16S rRNA gene similarity. The closest strain to strain KOME- $1^{\mathrm{T}}$ was Leptolinea tardivitalis $\mathrm{YMTK}-2^{\mathrm{T}}$ (1426 nt), with $92 \%$ sequence similarity. The sequence similarity between strains $\mathrm{KOME}-1^{\mathrm{T}}$ and GOMI-1 ${ }^{\mathrm{T}}$ was $92 \%$. These low sequence similarities strongly suggest that new genera and species should be created for each isolate.

To date, four cultured representatives have been described within the class Anaerolineae. Differential phenotypic characteristics of the four species of the Anaerolineae and our isolates are shown in Table 1. These organisms share several common phenotypic traits, e.g. filamentous morphology, strictly anaerobic metabolism and fermentative growth with a number of sugars in the presence of yeast extract. The thermophilic strain GOMI- $1^{\mathrm{T}}$ was very similar to the two thermophilic species within the genus Anaerolinea, A. thermophila and A. thermolimosa, in many physiological respects, but there were obvious phenotypic differences between them: (i) strain GOMI- $1^{\mathrm{T}}$ was able to grow at $65{ }^{\circ} \mathrm{C}$ and $\mathrm{pH} 8.5$, whereas the Anaerolinea species could not grow under such conditions, (ii) the isolate did not hydrolyse starch, while the Anaerolinea species showed significant starch hydrolysis, and (iii) strain GOMI- $1^{\mathrm{T}}$ has a cellular fatty acid composition that is easily distinguished from those of the Anaerolinea species. Phylogenetic analysis based on 16S rRNA gene sequences indicated that strain GOMI- $1^{\mathrm{T}}$ was distant from the genus Anaerolinea (the sequence similarities between strain GOMI- $1^{\mathrm{T}}$ and Anaerolinea species were lower than $90 \%$ ), and strongly suggested the creation of a new genus for the isolate (Fig. 2).

While the phylogenetic analysis showed that the other isolate, strain KOME- $1^{\mathrm{T}}$, was also distant from any known species in the class Anaerolineae, physiologically it resembled the mesophilic species within the class Anaerolineae, Levilinea saccharolytica and Leptolinea tardivitalis. However, strain KOME- $1^{\mathrm{T}}$ could be clearly differentiated from the related mesophiles by the following phenotypic differences (Table 1): (i) strain KOME- $1^{\mathrm{T}}$ had a narrow temperature range for growth and showed growth at $40{ }^{\circ} \mathrm{C}$ and (ii) strain KOME- $1^{\mathrm{T}}$ had a narrow nutritional range in substrate utilization and could not grow on glucose. In addition, a clear difference was found in syntrophic growth with a methanogen. Co-culture with a hydrogenotrophic methanogen enhanced growth of KOME- ${ }^{\mathrm{T}}$; similar enhancement was also found in the two species of the genus Anaerolinea (Yamada et al., 2005, 2006) and strain GOMI- $1^{\mathrm{T}}$, but was not observed in the mesophilic species belonging to the genera Levilinea and Leptolinea.

Based on the phenotypic and genetic comparisons mentioned above, we propose the names Bellilinea caldifistulae gen. nov., sp. nov., and Longilinea arvoryzae gen. nov., sp. nov., for strains GOMI- $1^{\mathrm{T}}$ and KOME- $1^{\mathrm{T}}$.

\section{Description of Bellilinea gen. nov.}

Bellilinea (Bel.li.li'ne.a. L. adj. bellus beautiful; L. fem. n. linea line; N.L. fem. n. Bellilinea beautifully line-shaped organism).

Gram-negative. Cells are non-motile. Multicellular and filamentous. Spores are not formed. Grow under strictly anaerobic conditions. No photosynthetic growth is observed. Thermophilic. The main fatty acids are $\mathrm{C}_{16: 0}$, $\mathrm{C}_{14: 0}$ and iso- $\mathrm{C}_{15: 0}$. The $\mathrm{G}+\mathrm{C}$ content of genomic DNA of the type strain of the type species is $54.7 \mathrm{~mol} \%$. Phylogenetic position is in the class Anaerolineae. The type species is Bellilinea caldifistulae.

\section{Description of Bellilinea caldifistulae sp. nov.}

Bellilinea caldifistulae (cal.di.fis'tu.lae. L. adj. caldus hot; L. n. fistula a tube, pipe; N.L. gen. n. caldifistulae of a hot pipe, referring to a thermophilic reactor vessel for wastewater/waste treatment, from where the type strain was isolated).

Cells are longer than $100 \mu \mathrm{m}$ and $0.2-0.4 \mu \mathrm{m}$ in width. Growth occurs between 45 and $65{ }^{\circ} \mathrm{C}$ with optimum 


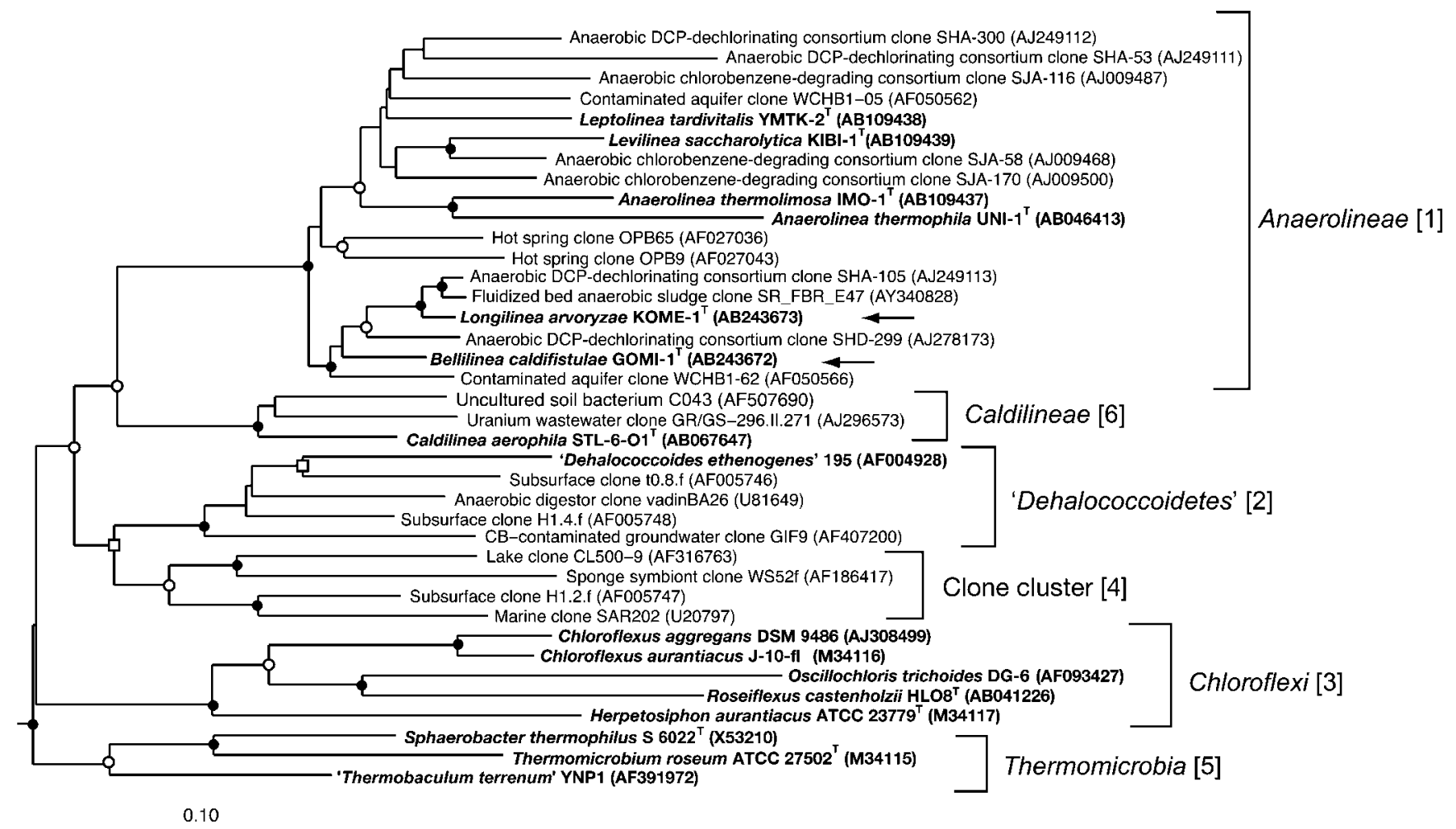

Fig. 2. Evolutionary dendrogram of the bacterial phylum Chloroflexi inferred from 16S rRNA gene sequences, showing the phylogenetic positions of strains $\mathrm{GOMl}-1^{\top}$ and $\mathrm{KOME}-1^{\top}$ (indicated by arrows). The sequences were aligned and the phylogenetic tree was reconstructed by the neighbour-joining method. 16S rRNA gene sequences of Escherichia coli ATCC $11775^{\top}$ (GenBank accession no. X80725), Bacillus subtilis 168 (D26185) and Corynebacterium diphtheriae NCTC $11397^{\top}$ (X84248) were used as outgroups (not shown). Bootstrap resampling analysis (Felsenstein, 1985) for 1000 replicates was performed with the PAUP* 4.0 program package (Swofford, 2002) for neighbour-joining and maximum-likelihood methods and with the TREEFINDER program (Jobb, 2007) for the maximum-likelihood method to estimate the confidence of the tree topologies. Branching points with support probabilities above $95 \%$ by all the analyses (estimated using neighbour-joining and maximumlikelihood methods) are indicated by solid circles, whereas nodes with open circles indicate $>85 \%$ bootstrap probability support by the two analyses. Nodes with open squares indicate $>75 \%$ probability support by both analyses. Nodes without symbols were not highly resolved $(<75 \%)$ as specific groups in the analyses. Bar, 10 nucleotide substitutions per 100 nucleotides. Class-level lineages in the phylum Chloroflexi are numbered (in brackets) according to the reports of Hugenholtz \& Stackebrandt (2004) and Yamada et al. (2006).

growth at $55{ }^{\circ} \mathrm{C}$. Growth is observed at $\mathrm{pH}$ 6.0-7.5 with optimum growth at $\mathrm{pH}$ 7.0. Doubling time for growth is $45 \mathrm{~h}$ under optimum growth conditions. Growth is enhanced in co-cultivation with hydrogenotrophic methanogens. Yeast extract is required for growth. In the presence of $0.01 \%$ yeast extract, growth is observed with the following substrates: ribose, arabinose, fructose, glucose, galactose, mannose, sucrose, raffinose and pectin. Weak growth occurs with the following substrates with medium supplemented with $0.01 \%$ yeast extract: Casamino acids, tryptone, peptone, xylose and xylan. The following substrates are not utilized in the presence of yeast extract: crotonate, $\mathrm{H}_{2} / \mathrm{CO}_{2}$ plus acetate, betaine, lactate, glycerol, fumarate, acetate, propionate, butyrate, malate, succinate, ethanol, methanol, 1-propanol, starch, ethylene glycol, hydroquinone, phenol, benzoate and formate plus acetate.
None of following compounds is utilized as an electron acceptor: sulphate, sulphite, thiosulphate, elemental sulphur, nitrate, fumarate and $\mathrm{Fe}(\mathrm{III}) \mathrm{NTA}$.

The type strain is GOMI- $1^{\mathrm{T}}\left(=\mathrm{JCM} 13669^{\mathrm{T}}=\mathrm{DSM}\right.$ $\left.17877^{\mathrm{T}}\right)$, which was isolated from thermophilic sludge in which sewage sludge and domestic garbage had been digested.

\section{Description of Longilinea gen. nov.}

Longilinea (Lon.gi.li'ne.a. L. adj. longus long; L. fem. n. linea line; N.L. fem. n. Longilinea long line-shaped organism).

Gram-negative. Cells are non-motile. Multicellular and filamentous. Spores are not formed. Grow under strictly anaerobic conditions. No photosynthetic growth is 
Table 1. Phenotypic characteristics of species with validly published names affiliated with the class Anaerolineae in the phylum Chloroflexi

Data for A. thermolimosa IMO- $1^{\mathrm{T}}$, Levilinea saccharolytica KIBI- $1^{\mathrm{T}}$ and Leptolinea tardivitalis $\mathrm{YMTK}-2^{\mathrm{T}}$ were obtained in our previous study (Yamada et al., 2006) and this study. Data for A. thermophila UNI- $1^{\mathrm{T}}$ were taken from Sekiguchi et al. (2003). -, Negative; \pm , variable; +, positive; ND, not determined. Only differences found among the strains are listed. All strains show the following characteristics: they form multicellular filaments; optimum growth at $\mathrm{pH}$ 7.0; no respiration of $\mathrm{O}_{2}$; positive for fermentation; no quinones detected; positive for utilization of yeast extract. All species show the same response for use of substrates in the presence of yeast extract as follows: sucrose, raffinose (positive); Casamino acids (variable); lactate, fumarate, acetate, succinate, ethanol (negative).

\begin{tabular}{|c|c|c|c|c|c|c|}
\hline Characteristic & $\begin{array}{c}\text { Bellilinea } \\
\text { caldifistulae } \\
\left(\text { strain GOMI-1 }{ }^{\mathrm{T}}\right)\end{array}$ & $\begin{array}{c}\text { Longilinea } \\
\text { arvoryzae } \\
\left(\text { strain KOME-1 }^{\mathbf{T}}\right)\end{array}$ & $\begin{array}{c}\text { Levilinea } \\
\text { saccharolytica } \\
\text { KIBI-1 }^{\mathrm{T}}\end{array}$ & $\begin{array}{l}\text { Leptolinea } \\
\text { tardivitalis } \\
\text { YMTK-2 }^{\mathrm{T}}\end{array}$ & $\begin{array}{c}\text { Anaerolinea } \\
\text { thermolimosa } \\
\text { IMO- }^{\mathrm{T}}\end{array}$ & $\begin{array}{c}\text { Anaerolinea } \\
\text { thermophila } \\
\mathrm{UNI}^{\mathrm{UN}} \mathrm{1}^{\mathrm{T}}\end{array}$ \\
\hline Temperature range $\left({ }^{\circ} \mathrm{C}\right)$ & $45-65$ & $30-40$ & $25-50$ & $25-50$ & $42-55$ & $50-60$ \\
\hline $\begin{array}{l}\text { Optimum growth } \\
\text { temperature }\left({ }^{\circ} \mathrm{C}\right)\end{array}$ & 55 & 37 & $37-40$ & 37 & 50 & 55 \\
\hline Doubling time $(\mathrm{h})^{*}$ & $45(29)$ & $92(38)$ & $56(56)$ & $50(50)$ & $48(10)$ & $72(48)$ \\
\hline Major cellular fatty acids & $\begin{array}{c}C_{16: 0}, C_{14: 0} \\
\text { i- } C_{15: 0}\end{array}$ & $\begin{array}{l}\mathrm{i}-\mathrm{C}_{15: 0}, \\
\text { ai- } \mathrm{C}_{15: 0}, \mathrm{C}_{14: 0}\end{array}$ & $\begin{array}{c}\mathrm{C}_{14: 0}, \mathrm{i}-\mathrm{C}_{15: 0} \\
\mathrm{C}_{16: 0}\end{array}$ & $\begin{array}{l}\text { Branched } C_{17: 0}, \\
\quad C_{16: 0}, C_{14: 0}\end{array}$ & $\begin{array}{l}\text { ai- } C_{17: 0} \\
\text { i- } C_{15: 0}, C_{16: 0}\end{array}$ & $\begin{array}{c}C_{16: 0}, C_{15: 0} \\
C_{14: 0}\end{array}$ \\
\hline DNA G $+\mathrm{C}$ content $(\mathrm{mol} \%)$ & 54.7 & 57.6 & 59.5 & 48.2 & 53.3 & 54.5 \\
\hline \multicolumn{7}{|l|}{$\begin{array}{l}\text { Utilization in the presence } \\
\text { of yeast extract of: }\end{array}$} \\
\hline Mannose & + & - & \pm & + & + & + \\
\hline Galactose & + & - & \pm & \pm & + & + \\
\hline Fructose & + & \pm & + & + & + & + \\
\hline Arabinose & + & - & - & \pm & + & \pm \\
\hline Xylose & \pm & - & + & + & + & \pm \\
\hline Ribose & + & - & + & + & + & \pm \\
\hline Pectin & + & + & \pm & + & \pm & \pm \\
\hline Starch & - & - & - & \pm & \pm & + \\
\hline Isolation source & $\begin{array}{c}\text { Thermophilic anaer- } \\
\text { obic sludge }\end{array}$ & $\begin{array}{l}\text { Rice paddy } \\
\text { soil }\end{array}$ & $\begin{array}{c}\text { Mesophilic } \\
\text { anaerobic sludge }\end{array}$ & $\begin{array}{c}\text { Mesophilic } \\
\text { anaerobic sludge }\end{array}$ & $\begin{array}{l}\text { Thermophilic } \\
\text { anaerobic sludge }\end{array}$ & $\begin{array}{c}\text { Thermophilic } \\
\text { anaerobic } \\
\text { sludge }\end{array}$ \\
\hline
\end{tabular}

${ }^{\star}$ Doubling times in parentheses indicate those in syntrophic growth with hydrogenotrophic methanogens.

observed. Mesophilic. The main fatty acids are iso- $\mathrm{C}_{15: 0}$, anteiso- $\mathrm{C}_{15: 0}$ and $\mathrm{C}_{14: 0}$. The $\mathrm{G}+\mathrm{C}$ content of genomic DNA of the type strain of the type species is $57.6 \mathrm{~mol} \%$. Phylogenetic position is in the class Anaerolineae. The type species is Longilinea arvoryzae.

\section{Description of Longilinea arvoryzae sp. nov.}

Longilinea arvoryzae (L. n. arvum an arable field, cultivated land; L. n. oryza rice; N.L. gen. n. arvoryzae of a rice paddy field).

Cells are longer than $100 \mu \mathrm{m}$ and $0.4-0.6 \mu \mathrm{m}$ in width. Growth occurs between 30 and $40{ }^{\circ} \mathrm{C}$ with optimum growth around $37^{\circ} \mathrm{C}$. Growth is observed at pH 5.0-8.5, with optimum growth around $\mathrm{pH}$ 7.0. Doubling time for growth is $92 \mathrm{~h}$ under optimum growth conditions. Growth is enhanced in co-cultivation with hydrogenotrophic methanogens. In the presence of $0.01 \%$ yeast extract, growth is observed with the following substrates: xylose, raffinose, sucrose, xylan, pectin and peptone. Weak growth occurs with Casamino acids and fructose in medium supplemented with $0.01 \%$ yeast extract. The following substrates are not utilized in the presence of yeast extract: pyruvate, glucose, ribose, arabinose, galactose, mannose, crotonate, $\mathrm{H}_{2} / \mathrm{CO}_{2}$ plus acetate, lactate, glycerol, fumarate, acetate, propionate, butyrate, malate, succinate, ethanol, methanol, 1-propanol, starch, ethylene glycol, hydroquinone, phenol, benzoate, formate plus acetate, betaine and starch. None of following compounds is utilized as 
an electron acceptor: sulphate, sulphite, thiosulphate, elemental sulphur, nitrate, fumarate and Fe(III) NTA.

The type strain is $\mathrm{KOME}-\mathrm{1}^{\mathrm{T}}$ (=JCM $13670^{\mathrm{T}}=\mathrm{KTCC}$ $5380^{\mathrm{T}}$ ), isolated from rice paddy soil soaked with water.

\section{Acknowledgements}

This study was carried out as part of a project entrusted to the New Energy and Industrial Technology Development Organization (NEDO), Tokyo, Japan. This study was also supported financially by research grant 1552481 from the Grants-in-Aid for JSPS Fellows and by several research grants from the Ministry of Education, Culture, Sports, Science and Technology, Japan. We thank Mizuho Muramatsu at the National Institute of Advanced Industrial Science and Technology (AIST) for her help with the determination of quinones, cellular fatty acids and DNA base contents. We also thank Masahiro Ito at Nagaoka University of Technology for his help with cultivation.

\section{References}

Björnsson, L., Hugenholtz, P., Tyson, G. W. \& Blackall, L. L. (2002). Filamentous Chloroflexi (green non-sulfur bacteria) are abundant in wastewater treatment processes with biological nutrient removal. Microbiology 148, 2309-2318.

Doetsch, R. N. (1981). Determinative methods of light microscopy. In Manual of Methods for General Bacteriology, pp. 21-33. Edited by P. Gerhardt, R. G. E. Murray, R. N. Costilow, E. W. Nester, W. A. Wood, N. R. Krieg \& G. B. Phillips. Washington, DC: American Society for Microbiology.

Felsenstein, J. (1985). Confidence limits on phylogenies: an approach using the bootstrap. Evolution 39, 783-791.

Hanada, S., Hiraishi, A., Shimada, K. \& Matsuura, K. (1995). Isolation of Chloroflexus aurantiacus and related thermophilic phototrophic bacteria from Japanese hot springs using an improved isolation procedure. J Gen Appl Microbiol 41, 119-130.

Hanada, S., Takaichi, S., Matsuura, K. \& Nakamura, K. (2002). Roseiflexus castenholzii gen. nov., sp. nov., a thermophilic, filamentous, photosynthetic bacterium that lacks chlorosomes. Int J Syst Evol Microbiol 52, 187-193.

Hiraishi, A. (1992). Direct automated sequencing of $16 \mathrm{~S}$ rDNA amplified by polymerase chain reaction from bacterial cultures without DNA purification. Lett Appl Microbiol 15, 210-213.

Hugenholtz, P. \& Stackebrandt, E. (2004). Reclassification of Sphaerobacter thermophilus from the subclass Sphaerobacteridae in the phylum Actinobacteria to the class Thermomicrobia (emended description) in the phylum Chloroflexi (emended description). Int $J$ Syst Evol Microbiol 54, 2049-2051.

Hugenholtz, P., Pitulle, C., Hershberger, K. L. \& Pace, N. R. (1998a). Novel division level bacterial diversity in a Yellowstone hot spring. J Bacteriol 180, 366-376.

Hugenholtz, P., Goebel, B. M. \& Pace, N. R. (1998b). Impact of culture-independent studies on the emerging phylogenetic view of bacterial diversity. J Bacteriol 180, 4765-4774.

Hungate, R. E. (1969). A roll-tube method for cultivation of strict anaerobes. Methods Microbiol 3B, 117-132.

Imachi, H., Sekiguchi, Y., Kamagata, Y., Ohashi, A. \& Harada, H. (2000). Cultivation and in situ detection of a thermophilic bacterium capable of oxidizing propionate in syntrophic association with hydrogenotrophic methanogens in a thermophilic methanogenic granular sludge. Appl Environ Microbiol 66, 3608-3615.
Imachi, H., Sekiguchi, Y., Kamagata, Y., Hanada, S., Ohashi, A. \& Harada, H. (2002). Pelotomaculum thermopropionicum gen. nov., sp. nov., an anaerobic, thermophilic, syntrophic propionate-oxidizing bacterium. Int J Syst Evol Microbiol 52, 1729-1735.

Imachi, H., Sekiguchi, Y., Kamagata, Y., Loy, A., Qiu, Y.-L., Hugenholtz, P., Kimura, N., Wagner, M., Ohashi, A. \& Harada, H. (2006). Non-sulfate-reducing, syntrophic bacteria affiliated with the Desulfotomaculum cluster I are widely distributed in methanogenic environments. Appl Environ Microbiol 72, 2080-2091.

Jobb, G. (2007). TREEFINDER, version of February 2007. Distributed by the author, Munich, Germany. http://www.treefinder.de

Kamagata, Y. \& Mikami, E. (1991). Isolation and characterization of a novel thermophilic Methanosaeta strain. Int J Syst Bacteriol 41, 191-196.

Kindaichi, T., Ito, T. \& Okabe, S. (2004). Ecophysiological interaction between nitrifying bacteria and heterotrophic bacteria in autotrophic nitrifying biofilms as determined by microautoradiographyfluorescence in situ hybridization. Appl Environ Microbiol 70, 1641-1650.

Ludwig, W., Strunk, O., Westram, R., Richter, L., Meier, H., Yadhukumar, Buchner, A., Lai, T., Steppi, S. \& other authors (2004). ARB: a software environment for sequence data. Nucleic Acids Res 32, 1363-1371.

Pfennig, N. \& Wagener, S. (1986). An improved method of preparing wet mounts for photomicrographs of microorganisms. J Microbiol Methods 4, 303-306.

Roden, E. E. \& Lovley, D. R. (1993). Dissimilatory Fe(III) reduction by the marine microorganism Desulfuromonas acetoxidans. Appl Environ Microbiol 59, 734-742.

Saitou, N. \& Nei, M. (1987). The neighbor-joining method: a new method for reconstructing phylogenetic trees. Mol Biol Evol 4, 406-425.

Sekiguchi, Y., Kamagata, Y., Syutsubo, K., Ohashi, A., Harada, H. \& Nakamura, K. (1998). Phylogenetic diversity of mesophilic and thermophilic granular sludges determined by $16 \mathrm{~S}$ rRNA gene analysis. Microbiology 144, 2655-2665.

Sekiguchi, Y., Kamagata, Y., Nakamura, K., Ohashi, A. \& Harada, H. (1999). Fluorescence in situ hybridization using 16S rRNA-targeted oligonucleotides reveals localization of methanogens and selected uncultured bacteria in mesophilic and thermophilic sludge granules. Appl Environ Microbiol 65, 1280-1288.

Sekiguchi, Y., Kamagata, Y., Nakamura, K., Ohashi, A. \& Harada, H. (2000). Syntrophothermus lipocalidus gen. nov., sp. nov., a novel thermophilic, syntrophic, fatty-acid-oxidizing anaerobe which utilizes isobutyrate. Int J Syst Evol Microbiol 50, 771-779.

Sekiguchi, Y., Takahashi, H., Kamagata, Y., Ohashi, A. \& Harada, H. (2001). In situ detection, isolation, and physiological properties of a thin filamentous microorganism abundant in methanogenic granular sludges: a novel isolate affiliated with a clone cluster, the green nonsulfur bacteria, subdivision I. Appl Environ Microbiol 67, 5740-5749.

Sekiguchi, Y., Yamada, T., Hanada, S., Ohashi, A., Harada, H. \& Kamagata, Y. (2003). Anaerolinea thermophila gen. nov., sp. nov. and Caldilinea aerophila gen. nov., sp. nov., novel filamentous thermophiles that represent a previously uncultured lineage of the domain Bacteria at the subphylum level. Int J Syst Evol Microbiol 53, 1843-1851.

Shintani, T., Liu, W.-T., Hanada, S., Kamagata, Y., Miyaoka, S., Suzuki, T. \& Nakamura, K. (2000). Micropruina glycogenica gen. nov., sp. nov., a new Gram-positive glycogen-accumulating bacterium isolated from activated sludge. Int J Syst Evol Microbiol 50, 201-207.

Swofford, D. L. (2002). PAUP ${ }^{*}$ : phylogenetic analysis using parsimony ( ${ }^{\star}$ and other methods), version 4 . Sunderland, MA: Sinauer Associates. 
Teske, A., Hinrichs, K. U., Edgcomb, V., de Vera Gomez, A., Kysela, D., Sylva, S. P., Sogin, M. L. \& Jannasch, H. W. (2002). Microbial diversity of hydrothermal sediments in the Guaymas Basin: evidence for anaerobic methanotrophic communities. Appl Environ Microbiol 68, 1994-2007.

Weisburg, W. G., Barns, S. M., Pelletier, D. A. \& Lane, D. J. (1991). 16S ribosomal DNA amplification for phylogenetic study. J Bacteriol 173, 697-703.

Yamada, T., Sekiguchi, Y., Imachi, H., Kamagata, Y., Ohashi, A. \& Harada, H. (2005). Diversity, localization and physiological properties of filamentous microbes belonging to Chloroflexi subphylum I in mesophilic and thermophilic methanogenic sludge granules. Appl Environ Microbiol 71, 7493-7503.
Yamada, T., Sekiguchi, Y., Hanada, S., Imachi, H., Ohashi, A., Harada, H. \& Kamataga, Y. (2006). Anaerolinea thermolimosa sp. nov., Levilinea saccharolytica gen. nov., sp. nov. and Leptolinea tardivitalis gen. nov., sp. nov., novel filamentous anaerobes, and description of the new classes Anaerolineae classis nov. and Caldilineae classis nov. in the bacterial phylum Chloroflexi. Int J Syst Evol Microbiol 56, 1331-1340.

Zhang, H., Sekiguchi, Y., Hanada, S., Hugenholtz, P., Kim, H., Kamagata, Y. \& Nakamura, K. (2003). Gemmatimonas aurantiaca gen. nov., sp. nov., a Gram-negative, aerobic, polyphosphateaccumulating micro-organism, the first cultured representative of the new bacterial phylum Gemmatimonadetes phyl. nov. Int J Syst Evol Microbiol 53, 1155-1163. 